\title{
Optimizing Kenmi Manipulation Courses of High School Sports Based on CDIO Model under the Background of Cloud Computing
}

\author{
Luosha Liu \\ Harbin University, Harbin 150086, China \\ Correspondence should be addressed to Luosha Liu; 1ls19740130@163.com
}

Received 30 August 2021; Accepted 3 November 2021; Published 19 November 2021

Academic Editor: Punit Gupta

Copyright (C) 2021 Luosha Liu. This is an open access article distributed under the Creative Commons Attribution License, which permits unrestricted use, distribution, and reproduction in any medium, provided the original work is properly cited.

Cloud computing is an increase, use, and delivery model of Internet-based services. It usually involves the provision of dynamic transactions and often virtualized resources through the Internet and provides the most reliable and secure data storage center. Therefore, cloud computing technology has features of cost saving and scalability. In view of this, the design and research of an autonomous learning platform based on the CDIO concept can make full use of cloud computing technology. The CDIO teaching model is a combination of theory and practice, closely linking the cultivation of knowledge, abilities, and personal qualities, subverting the previous education methods. Although it is an engineering field, it is based on an open system. Penetrating into all fields of education, the teaching methods of aerobics in colleges and universities are as practical as the CDIO teaching model and must be applied to practice. The independent learning ability, critical thinking, and team cohesion emphasized by the CDIO teaching model are also involved in the teaching of aerobics. CDIO is a key issue that needs to be solved urgently in talent training. CDIO is just a platform and framework. Under this framework, different schools and majors can integrate their own teaching systems and teaching content as needed. The reform of aerobics courses is guided by the educational framework and philosophy of CDIO and designed in accordance with the standards of CDIO. It is very important to plan the system and training of this course. This paper researches and analyzes the application of CDIO teaching mode in college sports aerobics under the background of cloud computing.

\section{Introduction}

With the engineering education concept of "integrated teaching plan," CDIO attaches importance not only to the cultivation of students' professional quality and basic theory but also to the improvement and development of students' sense of teamwork, communication skills, and innovative practical capabilities. It also attaches importance to the cultivation of students' comprehensive ability of system conception, design, implementation, and operation. CDIO is an open educational concept. Each school or educational institution can reform it according to its own actual situation, thereby optimizing educational resources and seeking its own development. The CDIO engineering education model is one of the new achievements of the international engineering education reform, which was first initiated and implemented by the Department of Aeronautics and
Astronautics of the Massachusetts Institute of Technology (MIT). The concept of CDIO engineering education is based on the whole life cycle of conception (conceive), designing (design), realization (implement), and operation (operate). Cultivate students' basic knowledge, engineering practice ability, independent learning ability and teamwork ability from four aspects to achieve expected goals [1,2]. Based on the training goals of applied talents, the CDIO model has been widely used in major universities. Liu and Zhang [3] studied cloud computing technology and application courses based on the concept of CDIO; Dai Xu et al. [4] proposed a software engineering application talent training program based on the concept of CDIO under the background of new engineering; Donghui et al. [5] proposed Research on the Flipped Classroom Teaching Model of CDIO Engineering Education Concept. CDIO engineering education concepts and blended teaching as emerging 
teaching concepts and methods provide useful reference and breakthroughs for the reform and improvement of teaching quality in universities. The requirements of enterprises for talents have also changed from "single discipline, independent work" to "interdisciplinary, teamwork." Enterprises require graduates to have engineering professionalism and good team coordination ability [6].

Starting in the 1970 s, China began to introduce aerobics courses. Through continuous development, aerobics courses have also become an important part of Chinese university education courses as one of the well-known courses. According to the investigation and research on the effects of aerobic exercise, it is found that aerobics can be integrated with very rich aesthetic elements and matched with dance. After a unique arrangement, aerobics can show the aesthetics of the human body. Therefore, it is also called "dance on the playground" in the western sports world. In 1982, Darly Siedentop, a well-known American sports scholar, proposed a sports education model at the Brisbane Federal Sports Conference in Australia. In the "Several Opinions of the Ministry of Education and Other Departments on Further Strengthening the Practice Education Work of Colleges and Universities," the practice education work is regarded as a reference for colleges and universities. It is also one of the important indicators of school quality and level evaluation [7-9]. The rapid development of today's society has created higher requirements for talent training. The new era requires high-quality talents with strong self-learning ability, cooperation ability, innovation ability, and strong critical thinking. The training of high-quality talents needs to update our traditions. Teaching concepts and teaching methods should abandon the old methods and introduce advanced teaching concepts into teaching to cultivate students' comprehensive abilities $[10,11]$. Chinese students lack practical experience in participating in projects and teamwork. Some developed countries in Europe and the United States have already walked ahead of us. The teaching concepts and methods used in these countries are worthy of our reference and research. Using CDIO's educational framework and concepts to guide the reform of aerobics education in colleges and universities and designing and planning the curriculum system and training plan of this course in accordance with CDIO standards have certain significance for colleges and universities to improve students' abilities and system expansion.

\section{Existing Problems}

The new curriculum reform requires teachers to pay more attention to the development of students and cultivate allround new talents that adapt to modern society. The university is an important stage in shaping all-round talents. In this stage, teachers should not only pay attention to students' professional knowledge and cultural courses but also pay attention to students' health and fitness. For this reason, in addition to regular and necessary health checks, in order to improve the physical fitness of students, schools should also develop appropriate physical fitness courses. Aerobics is a very good choice. With the deepening of China's higher education reforms, the emphasis on students' physical quality education has been strengthened in higher education, which has led to an increase in the proportion of sports courses in the curriculum. However, in the face of the teaching of a new type of aerobics, the existing teaching model still has many problems. Many teachers are still limited to traditional teaching thinking, only emphasizing the compulsory inculcation of skills, while ignoring students' experience and interest in the sport. There is a lack of effective interaction between teachers and students, teachers cannot grasp the students' personal physical conditions and psychological conditions in a timely manner, and students' acceptance of courses cannot be effectively fed back to teachers. The emergence of these problems is prompting college educators to reflect.

There are also problems of insufficient teachers and limited teachers' level, which objectively affects the teaching effect of bodybuilding classes. The lack of effective professional communication between limited professional teachers makes it difficult to promote each other's professional improvement, which exacerbates this problem. We still cannot get rid of the traditional teaching mode, which means that students are not the leaders of the classroom. At present, teachers still dominate the classroom, focusing on teachers "teaching" students and "learning." Students learn passively. Teachers teach in order to complete their teaching tasks. They do not pay much attention to whether students participate in teaching or whether students are autonomous learning. Teachers should try their best to let the students explore the problems that students can solve through their own efforts. For the content that must be explained, teachers should use the most essential language and the least time to complete the teaching and ultimately achieve the goal of improving the efficiency of college aerobics teaching.

The unity of teaching content restricts the use of the autonomous learning teaching mode. Aerobics is a sport that emphasizes continuity and collectiveness. Now, the teaching content of most colleges and universities is relatively simple and has no sense of rhythm, which cannot arouse students' interest in learning. In addition, teachers are mostly used in the classroom to demonstrate students' imitation and follow standard movements. There is no fresh activity in the classroom, which makes students tired of taking aerobics classes. Among college students, most of the students who prefer aerobics are female students. They hope to build a perfect body by learning aerobics. However, for some male students, they think that aerobics is not suitable for boys to learn. Aerobics must be learnt to keep fit. Students should always keep their views up to the pace of the times, so as not to derail with the times.

\section{Advantages of the CDIO Teaching Mode}

Table 1 is obtained by analyzing two teaching modes.

It can be seen from Table 1 that, in a short period of time, aerobics teaching allows students to accept new movements and master the learning content, which does not meet the requirements of the times for students' all-round development. Integrating the CDIO teaching model into college 
TABLE 1: Comparison of the CDIO teaching mode and traditional teaching mode.

\begin{tabular}{|c|c|c|c|c|}
\hline & Teaching method & Teaching objectives & Teaching philosophy & Teaching subject \\
\hline $\begin{array}{l}\text { Traditional } \\
\text { teaching mode }\end{array}$ & $\begin{array}{l}\text { Explain, teach, directly } \\
\text { inject dhamma, etc }\end{array}$ & $\begin{array}{l}\text { Pay attention to students' } \\
\text { technical movements and ignore } \\
\text { students' interest in learning }\end{array}$ & $\begin{array}{l}\text { Focus on theory and light on } \\
\text { practice, and on knowledge and } \\
\text { light on ability }\end{array}$ & $\begin{array}{c}\text { Teacher is the subject } \\
\text { and core }\end{array}$ \\
\hline $\begin{array}{l}\text { CDIO teaching } \\
\text { mode }\end{array}$ & $\begin{array}{l}\text { Inquiry learning } \\
\text { method, class and team } \\
\text { learning system, etc }\end{array}$ & $\begin{array}{l}\text { Pay attention to students' } \\
\text { practice and ability training, and } \\
\text { cultivate students' basic ability }\end{array}$ & $\begin{array}{l}\text { Advocate the integrated teaching } \\
\text { concept of "teach, learn and do" } \\
\text { and develop in an all-round way }\end{array}$ & $\begin{array}{c}\text { Focus on students and } \\
\text { advocate cooperation } \\
\text { between teachers and } \\
\text { students }\end{array}$ \\
\hline
\end{tabular}

aerobics classes provides students with the following three aspects of value: lasting learning motivation, multidimensional learning effects, and a relaxed learning environment. Learning motivation stimulates students' interest in learning and then stimulates and maintains students' learning behavior. The learning effect of students with long-term motivation is better than that of students with long-term motivation. Incorporating the CDIO teaching model into the aerobics classroom can make the originally monotonous, boring, and tasteless classroom full of vitality and mobilize the enthusiasm and initiative of students in learning, thereby inspiring students' interest in aerobics learning and students' lasting learning motivation and eliminating students who are tired of learning aerobics; in this learning motivation, students enjoy learning and reduce boring emotions in the learning process, and students can well achieve the teaching goals set by the teacher.

Taking 300 female students in an optional course of aerobics in a university as the research object, the two groups of students were taught in the same school year with the same equipment, the same progress, and the same content, and the same assessment methods were used for assessment. The teaching method of the experimental group adopts the CDIO teaching method, and the teaching method of the control group adopts the traditional teaching method.

It can be seen from Table 2 that the learning attitude of students in the experimental group is far better than that of the control group. This fully shows that, through the CDIO education model, students have a greater change in their attitude towards college aerobics, and they are more active. The learning environment is one of the external factors that affect learners' learning. It is an external condition that promotes learners to actively construct knowledge and promote ability generation. This teaching mode is studentcentered, the subjectivity of students is clearer, and students have more independence. The time for thinking and selfstudy is to ensure that students solve problems by themselves. The time for students' teamwork and class discussion is greatly increased. Students change from passive receivers of knowledge to active explorers, which is conducive to the digestion and absorption of knowledge and the cultivation of learning ability. Teachers can further emancipate their minds in higher education physical education, conduct teaching activities more calmly and effectively, and better cultivate modern talents.

As for aerobic exercise, we should pay special attention to the coordination of the students' limbs. Therefore, in the teaching process, attention should be paid to cultivating the flexibility of students' bodies and joints. Because female students have better flexibility than boys, female postural aesthetics should also be reflected in the design of aerobics movements. Only when the aesthetics is embodied, students can be inspired to participate in aerobic exercises. Students' autonomous learning must not only ensure sufficient time but also have the correct guidance of the teacher. For example, when the student learns aerobics, the teacher tells the students that you do a good job and are very standard, which is great for the students. Students who need your encouragement will be more confident and easier to find the direction of their efforts. Based on the needs of students, reasonable and rich teaching activities are designed. Contemporary college students are more receptive to new things. Teachers must use innovative teaching to make them attracted to the classroom. When students encounter difficulties, teachers will not. Instead of giving answers directly, students can further explore by setting the same situation or asking key questions, using appropriate guidance to stimulate students' curiosity and thirst for knowledge, stimulate students' thinking, and obtain information purposefully. Students play their own strengths and characteristics in a team and motivate each other, which is conducive to students' independent learning.

\section{Apply the CDIO Education Model to College Aerobics}

The CDIO outline divides students' abilities into four parts: basic knowledge ability, personal skills and work attitude, teamwork ability and communication ability, and systematic conception-design-implementation-application ability. The four abilities correspond to the four teaching goals. First, let students master the basic knowledge of aerobics in theory, and combined with specific practice, explain the principles, methods and steps of creating aerobics, and how to choose appropriate music and appropriate movements. Secondly, explain some basic music theory knowledge in the classroom, instruct students how to choose music in the process of arranging and exercises, and emphasize the integrity of the music and the complete set of movements, as well as the consistency of the phrase, rhythm, and movement, and help students understand the rhythm of the music. Through the coordination of music power and action power, the unity of music rhythm and action style is achieved. Teachers will further highlight the difficulties and key points of teaching. 
TABle 2: Comparison of students' learning attitudes.

\begin{tabular}{lcccc}
\hline & \multicolumn{2}{c}{ Control group } & \multicolumn{2}{c}{ Test group } \\
& Number of people & Proportion (\%) & Number of people & Proportion (\%) \\
\hline Interested in aerobics & 80 & 53.3 & 138 & 92.0 \\
Think learning is joyful & 76 & 56.6 & 143 & 95.3 \\
Learned to learn independently & 47 & 31.3 & 140 & 93.3 \\
Actively cooperate with teachers & 127 & 84.6 & 140 & 93.3 \\
\hline
\end{tabular}

Only in this way, they can distinguish between primary and secondary. Aerobics teaching can be conducted on campus or in the form of clubs. By cooperating with some clubs in society, more students can participate in club extracurricular activities, which will improve their sense of identity with aerobics teaching and sports and also improve their physical fitness.

The principle of "talk one, practice two, and do three": the main difference between the current domestic college physical education model and internationalization is that foreign countries are "speaking one practice, two doing three," while we are "teaching three, practicing two, and doing one." The education model of "speaking three, practicing two, and doing one" cannot fully trap students' self-learning ability and innovation ability and even seriously hinders the development of talents. And, this link just implements the principle of "speaking one, training two, and doing three," giving full play to the leading role of students. As students become familiar with the teaching mode and role-playing, they will have more creative choices for movements during the aerobics season. The main body of the competition will get greater play, and more time will be spent on the creation of the action formation and the competition. Through the creation of action formations, students' creativity, imagination, organization, and communication skills are fully stimulated. Through the competition, students can deepen their understanding of the operation of each link of the competition, improve their sports skills and tactical abilities in practice, and allow students to experience the fun of this sport in an all-round way. The cultivation of humanistic care and sports culture runs through the entire teaching process. The education model contains the following keywords: cooperation, competition, creation, celebration, awards, slogans, mascots, oaths, etc. Behind each keyword, the students have a unique cultural experience of aerobics. The all-round experience enhanced the students' sports cultural awareness and attracted more students to participate.

Teachers can play aerobics videos to allow students to enjoy performances and competitions of different levels, different projects, and different styles, so that students have an overall impression of aerobics performances. Then, divide the whole class into several groups according to the natural class, and each group has its own name (for example: Hyun Dance Team, Big Dipper, etc.), and each team carries out aerobics action combination, formation arrangement, modeling design, etc., according to its own characteristics. Music production and performance costume design: perform team program presentations in turn, record them onsite, and make them into CDs. This link fully demonstrates and excavates the students' personality and expressiveness and cultivates the students' sense of competition, spirit of collaboration, collective honor, and sense of accomplishment. Choose wonderful programs outside of class to participate in performances or competitions inside and outside the school to improve students' on-the-spot performance ability. Movement learning and creation: under the CDIO teaching mode, students' preclass learning is purposeful, principled, level-based, and guided by the teacher's specific learning methods. It is a good way for students to improve their learning ability. Teachers arrange in advance through the Internet, video, etc. Preclass tasks allow students to use all available resources and learning methods to complete part of the learning tasks.

\section{Results}

Teaching evaluation has the functions of improvement, feedback, value judgment, motivation, and guidance. Effective and scientific teaching evaluation is conducive to the implementation of the CDIO education model in college aerobics teaching. Learning evaluation is no longer an isolated behavior, and the evaluation content is more comprehensive. It not only emphasizes the evaluation of learning emotions, learning habits, learning attitudes, learning motivation, learning interest, and quality of will but also emphasizes the examination of learning ability and skills; secondly, pay more attention to integration and students' other evaluations, self-evaluations, and teacher evaluations. Teachers will give students more encouraging, instructive, and diagnostic comments during the evaluation, focusing on encouragement and reducing direct criticism; thirdly, it is necessary to achieve a variety of evaluation methods. The diversification of evaluation methods promotes the comprehensive training of teachers and students' abilities and is conducive to the establishment and improvement of the evaluation system and the exploration of a more advanced learning evaluation system. The DIO teaching model eliminates the disadvantages of traditional teaching evaluations such as focusing on knowledge, neglecting ability, focusing on results, and neglecting process in the assessment stage at the end of teaching, thereby optimizing students' learning methods and teachers' teaching methods and greatly improving teaching effects.

\section{Conclusion and Discussion}

The effective integration of the CDIO engineering education concept and the new teaching model derived from it into the online teaching process based on the low-cost and scalable 
operating platform of the cloud computing environment provides a good platform for China's online learning. The development and application can change the current situation of China's online teaching and promote the rapid development of China's online teaching. CDIO education model is not only a teaching practice model but also a value pursuit and an idea. Improving the effectiveness of college aerobics teaching has long been the common pursuit of the majority of college physical education teachers. It has become the fundamental requirement and key link in deepening the reform of college physical education elective courses. Compared with the traditional teaching model, it has more advantages. The application of aerobics teaching has lasting learning motivation, multidimensional learning effects, and a relaxed learning environment. Colleges and universities should actively exert creativity, explore and innovate in the teaching methods of aerobics, continuously innovate the teaching guiding ideology, introduce advanced CDIO teaching concepts, and be based on the aerobics major and not limited to this major.

\section{Data Availability}

No data were used to support this study.

\section{Conflicts of Interest}

The author declares no conflicts of interest.

\section{References}

[1] H. Dai and H. Da, "The software based on CDIO concept under the background of new engineering research on the training program for application-oriented talents in software engineering," Computer Education, vol. 64, no. 1, pp. 64-67, 2020.

[2] Z. Hu, S. Ren, and Z. Chen, "Engineering undergraduate talent training program project and its optimization: based on the concept of CDIO-CMM," Advanced Engineering Educational Research, vol. 36, no. 6, pp. 20-28, 2010.

[3] Y. Liu and N. Zhang, "Cloud computing technology and application based on the concept of CDIO research on curriculum teaching reform," Computer Age, vol. 21, no. 12, pp. 75-78, 2019.

[4] D. Xu, G. Liu, and W. Guo, Based on CDIO Engineering Education, Sanlian Bookstore, Shanghai, China, 2017.

[5] "Research on the flipped classroom teaching model of nian," Education and Teaching Forum, vol. 20, no. 13, pp. 316-318, 2020.

[6] J. Zhao and X. Gao, "About the implementation of undergraduate education with "students as the center" thinking of academic reform," China Higher Education Research, vol. 35, no. 8, pp. 36-40, 2017.

[7] Y. Li, "Teaching practice of software technology courses in applied undergraduate colleges research," Computer Education, vol. 29, no. 12, pp. 117-121, 2019.

[8] Study on the Difference of Cheerleading Management Systems in Universities in China and the United States, Hubei Sports Science and Technology, Hubei, China, 2017.

[9] R. Gao, J. Zhang, and H. Gao, Analysis on the Teaching Process Structure of Sports Education Model, Sanlian Bookstore, Beijing, China, 2018.
[10] S. Sim and H. Choi, "A study on the service discovery support method in the IoT environments," International Journal of Electrical Engineering Education, vol. 57, no. 1, pp. 85-96, 2020.

[11] H. Wang, X.-M. Zhang, G. Tomiyoshi et al., "Association of serum levels of antibodies against MMP1, CBX1, and CBX5 with transient ischemic attack and cerebral infarction," Oncotarget, vol. 9, no. 5, pp. 5600-5613, 2017. 